\title{
Prevalence of caries on permanent first molar on cerebral palsy children aged 6-12 years old in SLB Bandung at 2010
}

\author{
Devy Rizkyawati*, Meirina Gartika*, Jakobus Runkat* \\ *Departement of Pedodontics Faculty of Dentistry Universitas Padjadjaran
}

\begin{abstract}
Introduction: Caries is an irreversible tooth disease that is frequently encountered in the community. Caries on the permanent first molar, if not being treated, can cause tooth loss and other disadvantages. Cerebral palsy children have a motor abnormalities, that leads to high prevalence of caries. The purpose of this research was to find the prevalence of caries on the first permanent molar teeth in cerebral palsy children ages 6-12 years old. Methods: Type of research was descriptive research. Population is the cerebral palsy children in SLB Bandung, with criterion of children aged 6-12 years, has four permanent first molars, and no patches or restorations on permanent first molars. Samples from the population was taken by total sampling, a total of 26 cerebral palsy children. Results: The result shown that 22 cerebral palsy children $(84.62 \%)$ tends caries on their first permanent molar teeth. The prevalence of caries on the first permanent molar tooth of the maxilla of children with cerebral palsy is $76.92 \%$ and on the first permanent molar of the mandible is $78.84 \%$. Conclusion: Prevalence of caries on the first permanent molar teeth in cerebral palsy children ages 6-12 years old is high.
\end{abstract}

Keywords: Prevalence, cerebral palsy, molar, children.

\section{INTRODUCTION}

Health is a reflection of the quality of life of the community, the level of health in a country is also a preference of the quality of life of people in the country. Regulated in Law No.36 of 2009 on health, it is necessary to include development in the field of health, namely the improvement of humanitarian and nondiscriminatory health to raise awareness, willingness, and healthy living ability for everyone, in order to realize the highest degree of public health. Public health needs to be considered, including oral and dental health. According to WHO, the dental health of people within a country can be expressed by indicators of dental caries prevalence and periodontal disease and its severity. ${ }^{1}$ Caries is a non infectious tooth infection, so it gets less attention. The first permanent molar teeth occupy the top of the carious teeth as they are the first to erupt and have many pits and fissures. ${ }^{2}$ The first permanent molars of the eruption are not preceded by the deciduous teeth, so often people consider this to be the oldest to be replaced, so that it is less noticeable and left to be damaged. ${ }^{1}$

A person with carious tooth if untreated can suffer complete damage even tooth loss. The loss of a permanent first molars is very detrimental, 
because the tooth has many important functions. The first permanent molars are the largest contributors to chewing power. ${ }^{3}$, can be the key to occlusion, acting as a pillar between the anterior and posterior teeth in the oral cavity. ${ }^{4}$ protecting the dental supporting tissues to stay in good shape, and influential in the appearance and production of speech. ${ }^{5}$

It is the duty of the dentist as a health worker to pay attention to public health, including oral and dental health in children such as attention to the caries of children with special needs in the framework of equitable increase in public health status. The American Public Health Association defines children with special needs as children who are incapable of playing, walking, and working as do other children of the same age. Children with special needs lose their normal lives in a community because they have physical, mental, medical, or social limitations. ${ }^{6}$

These limitations do not become a barrier for children with special needs to get equal rights with normal children, whether they have the right to have a decent life, socialize, receive education, and also the right to health care. Dental and oral health often escape observation, especially in children with disabilities who are uncooperative of dental and oral care. One of the children with special needs is a child of cerebral palsy.

Cerebral palsy is a persistent, non-progressive brain damage, causing motor impairment of the body and motor of the mouth, causing the inability of the cerebral palsy child to clean his teeth and mouth. ${ }^{7}$ The absence of self cleansing effect, the high incidence of malocclusion, and the difficulty of swallowing, will result in poor oral hygiene conditions of the child's cerebral palsy, which may increase caries tendency. ${ }^{8,9}$

According to Pediatric Dental Health, more than 100,000 children and adolescents in the United States have cerebral palsy. ${ }^{10}$ The Collaborative Perinatal Project reports a prevalence rate of about four per thousand live births. ${ }^{11}$

Research conducted by Franky (1994) in RS Sanglah Denpasar showed that $58.3 \%$ of cerebral palsy patients studied were male, and $65.2 \%$ were the first child. ${ }^{12}$ The incidence of cerebral palsy in developing countries like Indonesia is higher than developed countries like the United States. The number of children and adults affected by cere- bral palsy slightly increased by 30 this year. According to Pediatric Dental Health, the incidence of caries in children with cerebral palsy is higher than that of normal children because of the condition of the teeth and mouth. ${ }^{10}$

In Denmark, in general, cerebral palsy children have a lower caries prevalence than normal children. ${ }^{13}$ According to the Irmaleny (1989) study, the prevalence of caries in the permanent teeth of cerebral palsy children in SLB-D YPAC Bandung was $95.5 \%$. The prevalence of caries in the permanent first molars of cerebral palsy children in Bandung is unknown.

According to Piaget, a person is categorized as a child until the age of 13 years. ${ }^{14}$ The permanent tooth begins to erupt at the age of six and the majority of eruptions until the age of 12 years. By looking at the condition of teeth in children of cerebral palsy age of six to 12 years can be seen whether or not there is delay in tooth growth.

This extraordinary school is a place for children with disabilities to get a proper education in order to achieve independence in their lives, as well as schools that provide educational facilities for normal children.Based on the data from the Extraordinary Department of Education Department of West Java Province, registered 45 Extraordinary Schools located in the city of Bandung.

The school for children with cerebral palsy is the Extraordinary School Part D, but due to various factors such as economic conditions, there are only a small number of cerebral palsy children who receive education at the Special Schools of the Other Section. In addition, children with cerebral palsy may also be accompanied by mental retardation, sensory abnormalities, seizures, hearing and vision, and behavioral abnormalities. ${ }^{15}$ in which cerebral palsy children can be detected at another part of the School of Extraordinary.

Therefore, the research was conducted at 45 Special Schools registered in Bandung City, in the hope of getting more samples representing the condition of children cerebral palsy in the city of Bandung.

The aim of this research is to know caries prevalence in permanent first molars of cerebral palsy children in SLB Bandung so that it can be considered in the plan of improvement program of dental and oral health in children of cerebral palsy. 


\section{METHODS}

The type of research is descriptive. Descriptive research is a method of research conducted with the main purpose to create a picture to describe a phenomenon ${ }^{16}$ Population is the cerebral palsy children in SLB Bandung, with criterion of children aged 6-12 years, has four permanent first molars, and no patches or restorations on permanent first molars. Samples are taken by total sampling technique, that is the whole population is taken as a sample. The sample size is 26 children.Location of research is SLB Bandung. Time of research was conducted in April-June 2010

\section{RESULTS}

Research on the prevalence of caries in permanent first molars of children of cerebral palsy of 6-12 years old in SLB Bandung in 2010 The study was conducted on 26 cerebral palsy children who meet the criteria of the sample. The results of the study are data analysis, where all the data obtained are arranged into the table through the calculation of the frequency distribution. Descriptive method of analysis shows the characteristics of research subjects by describing the results of research on the frequency table in the form of data obtained through the research. Characteristics of research subjects are outlined by age and region.

Table 1 shows the caries prevalence in the permanent first molars of cerebral palsy children by age. The prevalence of caries in children aged seven and eight years old is $3.85 \%$, nine and ten years old is $15.38 \%$, age 11 years old is $26.92 \%$ and age 12 years old is $19.23 \%$. The highest number of cerebral palsy children examined was 11 years of

Table 1. Prevalence of Caries in First Molar Teeth Permanent Childhood Cerebral Palsy By Age

\begin{tabular}{cccc}
\hline \multirow{2}{*}{ Age (years) } & \multicolumn{2}{c}{$\begin{array}{c}\text { Number of Cerebral } \\
\text { Palsy Children }\end{array}$} & Prevalence (\%) \\
\cline { 2 - 3 } & Examined & With caries & \\
\hline 7 years & 1 & 1 & 3.85 \\
8 years & 3 & 1 & 3.85 \\
9 years & 4 & 4 & 15.38 \\
10 years & 4 & 4 & 15.38 \\
11 years & 8 & 7 & 26.92 \\
12 years & 6 & 5 & 19.23 \\
\hline Total & 26 & 22 & $\mathbf{8 4 , 6 2}$ \\
\hline
\end{tabular}

age, with eight children and seven of them had caries on their permanent first molars. Table 2. shows the prevalence of cerebral palsy children who have caries in permanent first molars based on the region, highest in the 3.6 region with 21 children (80.77\%). Furthermore, regions 1.6, 2.6, and 4.6 have the same prevalence of 20 children each $(76.92 \%)$.

Table 2. Prevalence of Caries in First Molar Teeth Permanent of Cerebral Palsy Children Based on Region

\begin{tabular}{cccc}
\hline \multirow{2}{*}{ Age (years) } & \multicolumn{2}{c}{$\begin{array}{c}\text { Number of Cerebral } \\
\text { Palsy Children }\end{array}$} & Prevalence (\%) \\
\cline { 2 - 3 } & Examined & With caries & \\
\hline 1.6 & 26 & 20 & 76,92 \\
2.6 & 26 & 20 & 76,92 \\
3.6 & 26 & 21 & 80,77 \\
4.6 & 26 & 20 & 76,92 \\
\hline
\end{tabular}

\section{DISCUSSION}

Pediatric Dental Health states that the incidence of caries in children with cerebral palsy is higher than that of normal children due to impaired motor function. ${ }^{10}$ In Denmark, in general, cerebral palsy children have a lower caries prevalence than normal children. ${ }^{13}$ Based on research conducted by, from 265 elementary school students of second grade of age 6-8 year in Bandung, it is shown that the dental caries prevalence equal to $94.71 \% .^{16}$

The result of caries prevalence study on permanent first molars of cerebral palsy children in SLB Bandung in 2010 by researchers is $84.62 \% .{ }^{17}$ Results of research on prevalence of caries in permanent first molars of cerebral palsy children in SLB Bandung is $84.62 \%$, which shows a high prevalence. High prevalence may be obtained because $50 \%$ of cerebral palsy children have vomitus or vomiting, $50 \%$ have oral muscle motor disorders, and $69.23 \%$ often eat foods that are cariogenic.

Children with cerebral palsy who have vomitus or vomiting will excrete acid components from the abdominal contents by mouth. Acid liquids from the stomach in the mouth will wet the teeth, and make the environment of the mouth becomes acidic. An environment with a pH below 5.5 can cause demineralization of enamel. ${ }^{18}$

Frequent vomitus can cause erosion or loss of tooth structure. Teeth that have been eroded are more susceptible to caries. ${ }^{19,20}$ Oral motor dis- 
turbance is associated with difficulties in speech, mastication, and ingestion. ${ }^{7,21}$ Oral motor disturbance in children of cerebral palsy causes few (42.30\%) parents who are difficult to clean the teeth and mouth of their children to the maximum, making it difficult in avoiding the occurrence of caries. In the dental procedures used mouth prop to control the movement of the jaw that is not realized by the patient. ${ }^{9}$

During oral hygiene treatment in home, electric toothbrush can be used to help clean teeth in cerebral palsy children. An electric toothbrush has the ability to keep rotating under pressure. Children with cerebral palsy have difficulty in controlling ingestion, therefore it is necessary to note the appropriate use of toothpaste and it is safe if swallowed. The content of fluoride in the body that exceeds two ppm can cause flourosis. Mild fluorosis can lead to hypocalcification, and severe fluorosis can lead to enamel hypoplasia. Teeth with enamel hypoplasia will be more susceptible to caries. ${ }^{22}$

Another possible cause of high prevalence of caries in the permanent first molars of cerebral palsy children is that most $(69.23 \%)$ children with cerebral palsy often consume cariogenic foods. Type of carbohydrate foods with a sweet taste, especially sucrose. ${ }^{23}$ Parental affection shown by giving food that the children like without knowing about the risk of such a cariogenic diet may be the reason for the high caries in the cerebral palsy children.

Children's eating habits are strongly influenced by the way of education and educational background of their parents. Therefore, parents, especially mothers, are the main target of health education, especially concern in maintaining health, because parents are the model of their children's health behavior. ${ }^{16}$

Table 1 shows that 11 years old cerebral palsy children has the highest prevalence of caries in the permanent first molars. This happens because of the most frequency distribution of children aged 11 years compared to other ages. Caries does not has a greater risk of occurrence in adulthood. ${ }^{24}$ The highest risk of caries occur in permanent first molars is 1-2 years after eruption [3]. The eruption of permanent first molars are around the age of 6-7.5 years.

There are some children who have first per- manent molars, so that the first permanent molars still have no caries. This is because the samples taken are children who aged 6-12 years old, and delayed growth of teeth in cerebral palsy children. ${ }^{23}$, as $23.08 \%$ of cerebral palsy children who were examined to have delayed teeth growth. Delayed teeth growth can be seen from the number of teeth that have been erupted compare to the chronological age of the child.

Seen in Table 2, caries is present in almost every tooth region. This is due to the habit of cleaning teeth and mouth in cerebral palsy children, as much as $38.46 \%$ brushing teeth once a day or sometimes not certain. Cerebral palsy child is very dependent on others, especially the closest person or people around him like his parents, family, and teachers.

Therefore, the person closest to the child's cerebral palsy should have pay more attention to the child's oral hygiene and mouth.

Lack of attention of parents to the cleanliness of teeth and mouth of children who have cerebral palsy due to various limitations, such as the difficulty of controlling children, lack of knowledge of parents about the importance of maintaining oral hygiene, and various other difficulties.

Based on Table 2, it can be concluded that cerebral palsy children, mandibular molars have a higher caries prevalence than upper jaws. According to Black, the mandibular permanent first molars are usually the first to be attacked by caries, this is because the mandibular first molars of the lower jaw have a larger transversal fissure than the upper transverse fissures, there are also pits on the occlusal, buccal and lingual surfaces to facilitate the accumulation of food and debris. The mandibular first molar also the first to erupt compared to the upper jaw. ${ }^{3}$

The condition of drooling that occurs in the cerebral palsy is beneficial, it is shown from the results of the study that in children with cerebral palsy drooling showed less caries prevalence, that is $40.90 \%$, while in children cerebral palsy with no drooling is $59.09 \%$.

In drooling conditions, saliva will wet the surface of the tooth more often. Saliva is able to remove bacteria and food. Saliva is also able to re-deposit minerals, especially calcium and phosphorus, to maintain tooth integrity 25 
However, due to poor oral hygiene conditions in children, cerebral palsy causes caries in almost every tooth of a child's cerebral palsy.

\section{CONCLUSION}

Prevalence of caries in permanent first molars of children cerebral palsy in 6-12 years old is high.

\section{REFERENCES}

1. Riani D, Sarasati. Peranan Pola Makan terhadap Karies Gigi pada Anak. Jurnal Kedokteran Gigi Indonesia PDGI. 2005;55(1)14-18 pp.

2. Tarigan, Rasinta. Karies Gigi. Jakarta: Hipokrates. 1995. 48 pp.

3. Ash MM, Nelson MJ. Wheeler's Dental Anatomy, Physiology, and Occlusion. $8^{\text {th }}$ Ed. St. Louis: Elsevier Saunders. 2005. 26-32, 154-158 pp.

4. Foster TD. Buku Ajar Ortodonsi. $3^{\text {th }}$ Ed. Jakarta: EGC. 1997. 22-24, 42-44, 99-102, 117-118 pp.

5. McDonald RE, Avery DR. Dentistry for The Child and Adolescent. $7^{\text {th }}$ ed. St. Louis: C.V. Mosby Company. 2000. 247, 261 pp.

6. Waldman HB. Almost four million children with disabilities. ASDC J. Dent Child. 1995. 62-3; 205-9 pp.

7. Neiva FC, Cattoni DM, Ramos JL, Issler H. Early Wearing: Implication to Oral Motor Development. J Pediatr (Rio J). 2003 JanFeb;79(1):7-12.

8. Rosenstein SS. Dentistry in Cerebral Palsy and Related Handicaping Conditions. Illinois. Charle C. Thomas Publisher. 1978. 304 pp.

9. Scully C, Cawson RA. Medical Problems in Dentistry. $4^{\text {th }}$ Ed. Toronto: Wright. 2003. 18-29 pp.

10. Inga CJ, Reddy AK, Richardson SA, Sanders B. Appliance for chronic drooling in cerebral palsy patients. Pediatr Dent. 2001 MayJun;23(3):241-2.

11. Nelson. Ilmu Kesehatan Anak. 15 th Ed. 15(3). Jakarta: 2000. 2080-9 pp.

12. Ilma A, Ningsih L. Asuhan Keperawatan Anak dengan Cerebral Palsy. 2009.
13. Koch, Goran, Poulsen S. Pediatric Dentistry - a Clinical Approach. $3^{\text {th }}$ Ed. Copenhagen: Munksgaard. 2001. 253-263, 273-280 pp.

14. Kartono, Kartini. Perkembangan Anak (Psikologi Perkembangan). Bandung : Penerbit Mandar Maju. 1995. 22 pp.

15. Cohen MM, Bhaskar SN. Pediatric Dentistry. $2^{\text {nd }}$ Ed. St. Louis: The C.V. Mosby Company. h. 1961. 216-221, 287-9 pp.

16. Notoatmodjo S. Metodologi Penelitian Kesehatan. $2^{\text {nd }}$ Ed. Jakarta: PT Rineka Cipta. 2002. 88-92 pp.

17. Ririn. Timah Hitam Dapat Menyebabkan Karies Gigi. Suara Pembaruan Daily. 2005. 41 pp.

18. Ford TRP. Restorasi Gigi. $2^{\text {nd }}$ Ed. Jakarta: EGC. 1993. 11-14 pp.

19. Baum L, Phillips RW. Buku Ajar Ilmu Konservasi Gigi. $3^{\text {th }}$ Ed. Jakarta: EGC. 1997. 1-25, 34-50 pp.

20. Narendra MB, Sularyo TS. Tumbuh Kembang Anak dan Remaja. Jakarta: Sagung Seto. 2002. 100-104 pp.

21. Degano MP. Breast Feeding and Oral Health. A Primer for The Dental Practitioner. New York: Churchill livingstone. 1993. 30-32 pp.

22. Cameron AC, Widmer RP. Handbook of Pediatric Dentistry. $2^{\text {nd }} E d$. Philadelphia: Mosby. 2003. 28-42 pp.

23. Herawati D, Utomo RB. Penilaian Status Gizi Anak Palsi Serebral. Majalah Kedokteran Gigi. Yogyakarta: FKG UGM. 2007;14. 177-182 pp.

24. Schuurs AHB, Moorer WR. Patologi Gigi-Geligi: Kelainan-Kelainan Jaringan Keras Gigi. Yogyakarta: Gadjah Mada University Press. 1993. 30-42, 46-55, 59-114 pp.

25. Manson JD, Eley BM. Buku Ajar Periodonti. $2^{\text {th }}$ Ed. Jakarta: Hipokrates. 1993. 1-3, 44-48, 55$57 \mathrm{pp}$.

26. Weyman J. The dental Care of Handicapped Children. Churchill. Livingstone. Edinburgh. London. Longman group limited. 1971. 98 pp.

27. Mae Cin RDH, Fenton SJ, Lyons R, Miller C, Perlman SP. Tesini D. Practical Oral Care for People With Cerebral Palsy. NIH Publication. 2009. 1-8 pp. 